\title{
Development Of Wind's Maze Chemistry Game Based On Android As A Learning Media On Hydrocarbon Matter For Eleventh Grade Senior High School
}

\author{
Winda Dwi Fitria, Achmad Lutfi \\ Chemistry Education Program, Undergraduate, \\ Universitas Negeri Surabaya \\ Surabaya, Indonesia \\ achmadlutfi@unesa.ac.id
}

\begin{abstract}
This study aims to obtain a game of Wind's Maze Chemistry based on android which is suitable to be used as learning media on main Hydrocarbon subject for eleventh grade of Senior High School's based on the validity, practicality, and effectiveness of the game. The type of this study uses research and development ( $R \& D)$ methods with stages 1) Preliminary study, 2) Development and validity, and 3) Game trials. But, this study is only done until limited trial stage. Limited trials were conducted in XI MIA 3 SMA Negeri 1 Taman-Sidoarjo on the second semester of the 2017/2018 school year. The instrument which used in this study is game validation sheet by 2 chemistry lecturers and 1 chemistry teacher to know the validity of the game, students' response questionnaire sheet and supported by observation sheet of learners activity to know the practicality, and also test sheet to know the effectiveness of the game. The results showed that: 1) the validity of the game by obtaining highly valid category with $88.25 \%$ percentage based on the content validity and construct validity criteria with $90 \%$ and $88 \%$, respectively 2) the practicality of the game by obtaining very practical category with the percentage of $83,75 \%$ based on students' response questionnaire and supported by relevant learners activity of $94.44 \%$ and irrelevant activity of $5.56 \%$; and 3) the effectiveness of the game in terms of classical completeness and the scores with a percentage of $75 \%$ each with effective category and equal to $90 \%$ with very effective category. Based on these results, it can be concluded that the game of Wind's Maze Chemistry based on Android can be used worthy as a learning media on the main Hydrocarbon subject for eleventh grade of Senior Hight School's.
\end{abstract}

Keywords- Wind's Maze Chemistry game, based on Android, learning media, Hydrocarbon

\section{INTRODUCTION}

Education is a bridge of the reality of life that students will face in the 21 st century so that the education system must prepare learning patterns that are in accordance with the times that students will face. One of the learning patterns developed in the 2013 curriculum is multimediabased and interactive learning in which there is an active relationship between teachers and students [1].

Chemistry learning material in high school studies the composition, structure, traits, and changes in material and accompanying energy and involves skills and reasoning. One important material taught in chemistry learning is hydrocarbons. Hydrocarbon material is quite difficult to understand because it involves reasoning and there are some students who have not been completed in this material.
There are many types of chemical bonds on carbon compounds with different functional groups so that to understand this is certainly not enough just by reading books, students must practice more to improve understanding [2]. The provision of interactive learning media in the form of games can help students to practice working on hydrocarbon-related questions anywhere and anytime, even without being accompanied by the teacher.

Based on the results of a questionnaire given to 60 students in a accredited High Schools in Surabaya and Sidoarjo, it was stated that $80 \%$ of students had difficulties in learning chemistry and as many as $58.33 \%$ of students stated that the subject of hydrocarbons was difficult to understand. Students tend to find it difficult to work on every hydrocarbon problem including naming alkanes, alkenes, and alkyas [3]. In addition, the level of understanding of students about the use of hydrocarbon compounds in everyday life so that many do not know the benefits. Conditions like this are caused by several factors both from the students themselves who do not want to understand further or in the learning process carried out by the teacher on the subject of theoretical Hydrocarbons using only media in the form of LKS, so that students tend to be passive and feel bored. The media used is only in the form of text without audio. Conventional learning leads to ineffective learning of students and does not feel motivated by students, so that students lack or do not understand the material provided by the teacher [4].

Innovation is needed to realize the hope of improving learning outcomes in the teaching and learning process. The existence of renewal is to develop learning media that is interesting, feasible and effective by combining between Android-based games and inside it contains chemical material. Learning media in the form of games that are educational on mobile phone (android) is effective as a learning medium that can help students' understanding so that it can improve learning outcomes [13] [9]. Another advantage is the active participation of students to learn because the Wind's Maze Chemistry game is done individually but can work together to work on questions that are in the game, interesting, entertaining, and the game application can be disseminated.

The game of Wind's Maze Chemistry is a tutorial genre game which in the presentation of the material is done in a tutorial and then there is a practice question that discusses 
and contains questions about hydrocarbon compounds [5]. This game is a maze game that can be played by students by directing players to find a way out by taking the coins provided and avoiding the bombs because if the player hits a bomb then the player's life will decrease. The game using maze can optimize learning independently as expected in the constructivism theory that students find and transform information obtained on themselves [6].

Based on the description above, a game of Wind's Maze Chemistry was developed which was used as a learning medium for the XI SMA high school grade material. The purpose of this study is to obtain a game that is suitable to be used as a learning medium in class XI high school hydrocarbons.

\section{METHODS}

This type of research is $\mathrm{R} \& \mathrm{D}$ research and development adapted from Sukmadinata [7]. The stages of research and development are (1) preliminary study, 92) development and validity, and (3) game testing. However, in this study only limited to the limited testing phase. The following is the flow of the research method in Figure 1 and an explanation of each stage of the research.

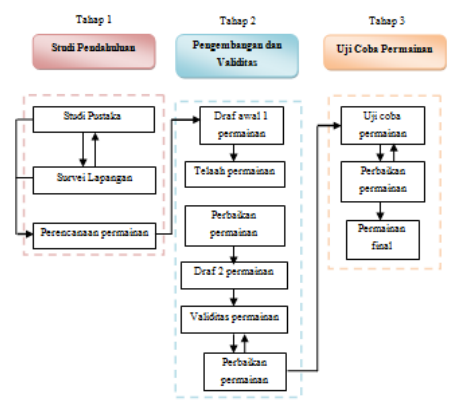

Fig. 1 Stages of Modification Research and Development [7]

\section{A. Preliminary Study}

At this stage it is carried out based on literature studies and field studies that are used to describe and analyze what has been obtained, resulting in a product design.

a. Literature study, at this stage will examine the relevant learning theory in the game, the characteristics possessed by students, and the results of previous research.

b. Field Survey, this stage is carried out by conducting interviews with students in class XI and chemistry teachers. The interviews were also conducted by giving pre-research questionnaires. The contents of the interview and questionnaire include the media, facilities, learning resources of students, and analysis of students.

c. Game Planning, game plan in the form of storyboard. In addition to compiling material and questions related to hydrocarbon material in games based on learning objectives.

\section{B. Development and Validity}

This stage aims to obtain the results of game validity. This development phase includes several steps, namely:

a. Game planning has been done, it will produce an initial draft of the game.

b. Game review, this was done to get advice and input from media experts and material experts as the initial draft of the game. The reviewer will examine the game that will be tested for students.

c. Game improvement, this was done to improve the draft of the game according to suggestions and input from media experts and material experts.

d. Game validity, this is done after the game has been improved. Material experts and media experts as many as 3 people, namely 2 lecturers and 1 chemistry subject teacher will validate the game that has been improved, including content validity and construct validity. The score is based on the Likert scale score in Table I.

TABLE I. LIKERT SCALE SCORE

\begin{tabular}{|c|c|}
\hline Statement & Value/Score \\
\hline There is no component & 0 \\
\hline Very Less & 2 \\
\hline Very Less & 3 \\
\hline Less & 4 \\
\hline Good & 5 \\
\hline Very Good
\end{tabular}

The results of the assessment are analyzed in each indicator with the formula:

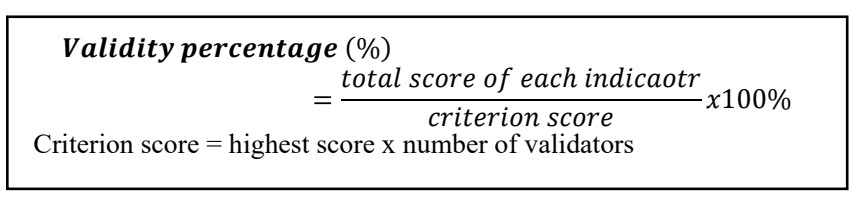

The game is said to be valid if each indicator on the validity aspects of the game gets valid criteria, namely $\geq 61 \%$. e. If the validity of the game has not fulfilled, the repairs will be carried out then the game will be validated again.

\section{Game Trial}

At the trial stage the game aims to obtain data on the practicality and effectiveness of the game. The trial was conducted on 20 students of class XI MIA at TamanSidoarjo Public High School 1 using the One Group PretestPostest Design system, that is, students prior to learning using the game were given a pre-test and after playing the post-test questions were given and filled out the response questionnaire . During the learning activities students' activities were observed.

\section{1) Game Practicality}

The practicality of the game Wind's Maze Chemistry was obtained based on the responses of students and supported by observations of the activities of students while using the game. After the post-test, students were asked to fill out a response questionnaire to find out the practicality of the game Wind's Maze Chemistry. This questionnaire was assessed in a quantitative descriptive manner based on Table II.

\begin{tabular}{|c|c|} 
TABLE II. GUTTMAN SCALE SCORE \\
\hline Answer & Statement Score \\
\hline Yes & 1 \\
\hline No & 0 \\
\hline
\end{tabular}

The data obtained will be analyzed using the formula:

Percentage of practically (\%)

$$
=\frac{\text { total score of each statement }}{\text { number of respondents }} \times 100 \%
$$

The game is said to be practical if it gets a practical criterion of $\geq 61 \%$. 
In addition, during the play, students' activities that were relevant and irrelevant were observed when the product trial took place as supporting data on the practicality of the game Wind's Maze Chemistry using the formula:

$$
\mathrm{P}=\frac{\sum_{i i}}{\sum \%} \times 100 \%
$$

Information:

$\mathrm{P}=$ Percentage of student activity

$\Sigma \mathrm{Xi}=$ number of observations on observed aspect

$\Sigma \mathrm{N}=$ maximum number of observations for each aspect

\section{2) Game Effectiveness}

The effectiveness of the Wind's Maze Chemistry game is obtained based on classical gain-scores and completeness. Here's the formula for calculating gain-scores:

$$
g=\frac{\text { Spostest }- \text { Spretest }}{\text { Smax }- \text { Spretest }}
$$

Based on the gain scores obtained then adjusted to the Gain score criteria in Table III.

TABLE III. GAIN SCORE CRITERIA

\begin{tabular}{|c|c|}
\hline Gain Score & Category \\
\hline $\mathrm{g} \geq 0,7$ & Height \\
\hline $0,7>\mathrm{g} \geq 0,3$ & Medium \\
\hline $\mathrm{g}<0,3$ & Low \\
\hline
\end{tabular}

Based on the gain score criteria, the game Wind's Maze Chemistry can be said to be effective if the results of students' learning improvement on the average gain score reached $>0.7$ with a high criterion or a gain score of sedang 0.3 with a medium criterion.

In addition, classical completeness is used to determine the effectiveness of the game being developed. Students are said to be complete if the minimum score obtained reaches a range of 78 in accordance with the KKM from the school.

$$
\begin{aligned}
& \text { Effectiveness percentage (\%) } \\
& =\frac{\text { total number of students completed }}{\text { number of students }} \times 100 \%
\end{aligned}
$$

The game is said to be effective if it gets an effective criterion of $\geq 78 \%$.

\section{RESULT AND DISCUSSION}

The following are the results of the research and discussion of the development of the game Wind's Maze Chemistry as a learning medium in the subject matter of the XI SMA Hydrocarbon subject matter as described below:

\section{A. Preliminary Study Phase}

The preliminary study phase is the initial stage or preparation for development which includes the following three stages:

\section{1) Literature review}

Literature study is a study to learn concepts or theories related to the game being developed. In the literature study phase, the activities carried out are analyzing the curriculum used in schools and learning learning theories related to learning to use games.
Learning theory that supports the use of games as learning media is Piaget's cognitive theory, Skinner's theory of behaviorism, and constructivism theory. Piaget argues that the development for ages 11 and older or high school children is included in cognitive development, namely formal operations. Skinner argues that learning is a behavior change due to the presence of repeated responses that are controlled by the consequences. If a person's behavior is immediately followed by pleasant consequences, the person tends to repeat the behavior [14]. The game as a learning media acts as an aid in scaffolding according to constructivism theory.

\section{2) Field Survey}

At this stage analyzed the learning media and learning resources used in schools based on preliminary research found that $80 \%$ of students considered difficult chemistry lessons due to boring learning with learning media that is often used, namely power points and worksheets and difficult materials, especially hydrocarbons with $60 \%$ percentage. As many as $72 \%$ of students stated that hydrocarbon material was difficult to learn because it was less motivated in learning and needed a medium that could make the learning atmosphere fun and motivating [3]. Therefore, learning media are needed that can generate learning passion and clarify the presentation so that it is not too verbalistic with the game. This is evidenced by $70 \%$ of students wanting the game to be used at the time of learning. Games can be an effective way to get the attention of students to learn a specific topic [8].

\section{3) Game Planning}

This stage the researcher composes the game design in the form of storyboards and game use guide books. The game that will be developed contains material and questions related to hydrocarbon material based on learning objectives. indicators and learning objectives are adjusted to the KI and KD contained in the 2013 curriculum that is currently applied so that nothing is excessive or lacking.

The flow of the Wind's Maze Chemistry game starts with a menu display that contains play, author, learning indicators and game rules. When the player chooses to play, the player avatar will appear which must be selected. After selecting an avatar, level 1, level 2 and level 3 will appear, but for the first time level 2 and level 3 are still locked. Each level has the shape of a maze that varies according to the level of difficulty. Players are required to get 3 coins in the form of an atom to answer the question and the player must get a door as the end of each level. If you have completed all levels or three levels then at the end of the game the score will appear.

\section{B. Development and Validity}

This stage aims to produce a game of Wind's Maze Chemistry that can be used as a learning medium. The steps taken are:

1) Drafting the Beginning of the Game

The components previously explained are storyboarding and game guide books called the initial draft 1 . 


\section{2) Game Review}

At this stage, the review of the game was reviewed by material experts and media experts, namely in this case the chemistry lecturer to get suggestions and input so that the game developed in accordance with the criteria that have been set using the study sheet that has been made. Review is the first step to support the stage of game validity. The criteria assessed are content validity and construct validity.

\section{3) Game Repair}

At this stage, the game will be improved related to suggestions and input at the review stage that is not in accordance with the expected criteria. Here is one example of improvement after the review process, namely the absence of the university logo on the author's menu in Figure 2a, then the repairs are carried out as shown in Figure $2 \mathrm{~b}$.

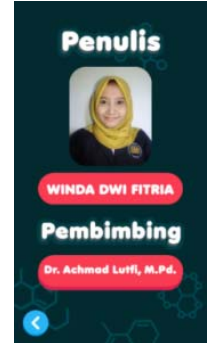

Fig. 2a

Display before

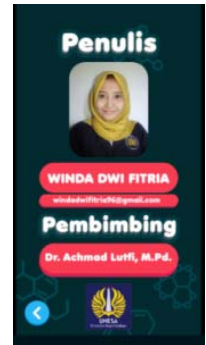

Fig. 2b

Display after

\section{4) Game Validity}

Assessment by 2 chemistry lecturers and 1 chemistry teacher from Taman Negeri 1 Sidoarjo to find out the validity of the game developed. Validity consists of 2 aspects, namely content validity and construct validity which can be seen in Table 4 .

\begin{tabular}{|c|c|c|}
\multicolumn{2}{|c|}{ TABLE IV VALIDATION RESULTS } \\
\hline Validity & $\begin{array}{c}\text { Persentase Tiap Aspek } \\
\mathbf{( \% )}\end{array}$ & Kategori \\
\hline Content & $86,67-93,33$ & Very valid \\
\hline Construction & $80-100$ & $\begin{array}{c}\text { Valid - Very } \\
\text { valid }\end{array}$ \\
\hline
\end{tabular}

Content validity consists of 2 aspects that are assessed, namely the truth of the concept and having goals which each get a percentage of $93.33 \%$ and $86.67 \%$ with very valid criteria. Games as learning media are used to convey learning messages so that students can remember what they have learned. Therefore, the message given in the form of material and questions must be in accordance with the learning objectives and characteristics of students [5]. The game Wind's Maze Chemistry has fulfilled the aspect of content validity because learning media must be in accordance with the learning objectives and needs of students both in the form of media and the level of difficulty [15].

There are 12 aspects that are assessed on construct validity namely encouraging developing specific skills, suitability with the characteristics of students, having rules, guiding nature, the existence of competition, requirements, challenges, and strategies in playing, the existence of standards of success, challenging and involving students, providing feedback back, has elements of decision making, display as learning media, software engineering, and audio visual communication. Each indicator gets a percentage of validity in the range of $\geq 61 \%$ which is included in the valid and very valid criteria [16]. The game Wind's Maze Chemistry has fulfilled the aspect of construct validity because the criteria in choosing a game as a learning medium are an attraction for students [5]. When the game is interesting, students can easily store information well and be stored for a long time.

In this second stage, the development and validity of the game to get results in the form of game validity. The validity of the game is one of the requirements of the game Wind's Maze Chemistry, which is declared feasible as a learning medium in the subject matter of Hydrocarbons. Based on the results of the study and the validity of the game, the game Wind's Maze Chemistry gets a validity percentage of $88.25 \%$ with a very valid category.

\section{Game Trial}

The Wind's Maze Chemistry game developed after being assessed and declared valid for use as a learning medium was then tested on 20 students of class XI MIA Taman-Sidoarjo Public High School 1 who were selected heterogeneously based on their abilities by observing the activities of students by 4 observers.

\section{1) Game Practicality}

The practicality of the game Wind's Maze Chemistry was obtained from the results of the questionnaire responses of students and supported by observations of students who were received by 4 observers within 60 minutes.

The results of the students' responses were obtained from the questionnaire responses given to students after using the game Wind's Maze Chemistry. The following are the results of the questionnaire responses of students in Table 5 .

TABLE V RESULTS OF RESPONSE

\begin{tabular}{|c|c|c|}
\hline Aspects & Percentage & Category \\
\hline Interest & $83,75 \%$ & Very practical \\
\hline Update & $100 \%$ & Very practical \\
\hline Usefulness & $93 \%$ & Very practical \\
\hline Convenience & $90 \%$ & Very practical \\
\hline Linguistic & $100 \%$ & Very practical \\
\hline
\end{tabular}

In the aspect of interest in the game get a percentage of $83.75 \%$ because the game Wind's Maze Chemistry is fun because it combines playing while learning so that students feel happy when tested. The game is something fun and entertaining to do [9]. Wind's Maze Chemistry is a newly developed game and students have never received a game like this before on Hydrocarbon material so they get a percentage of $100 \%$. The usefulness aspect of the game uses Android to learn while playing. In addition, learning refers to the use of information and communication technology (mobile devices) as a learning medium so that students can access the material without being limited by space and time [10].

The ease of using the game means that all students can install the game Wind's Maze Chemistry without any obstacles. Linguistic aspects get a percentage of $100 \%$ which states that students have no difficulty in understanding the language used in the game. This is because the language used in the game Wind's Maze Chemistry is Indonesian as the language used daily. This is 
in accordance with the 2013 curriculum which states that the use of teaching language is Indonesian in achieving learning goals [11].

The following is a comparison of the activity aspects of students in Figure 3.

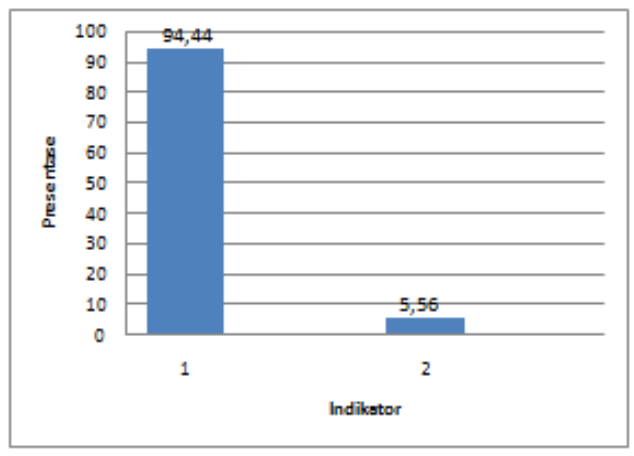

Fig. 3 Results of Student Activities

Information:

1 = Activities of relevant students while using the game Wind's Maze Chemistry

2 = Activities of students who are irrelevant while using the game Wind's Maze Chemistry

It is known that the relevant activities in the form of participation and interest data get a percentage of $94.44 \%$ while irrelevant activities get a percentage of $5.56 \%$. This shows that students are active to participate in using the Wind's Maze Chemistry game as a learning medium. This can support the students' response data to know the practicality of the Wind's Maze Chemistry game because the percentage of relevant student activity is higher than the irrelevant activities of students.

\section{2) Game Effectiveness}

The effectiveness of the Wind's Maze Chemistry game is obtained from students' learning outcomes data. This learning test results from the pre-test (before) and posttest (after) values using the Wind's Maze Chemistry game. This test aims to determine the achievement of learning objectives using the Wind's Maze Chemistry game as a learning medium.

There were 20 students who were tested for the development of the Wind's Maze Chemistry game as a learning medium. The heterogeneous selection of students is based on upper level (smart), middle (medium), and lower (less intelligent) than the previous semester's score. This is because the game developed can be used by all students to help understand hydrocarbon material.

Classical completeness at the pretest (before using the Wind's Maze Chemistry game) got a percentage of 20\%, while after using the game (posttest) got a percentage of $80 \%$. This is because not all students can master the subject matter in a shorter period of time. Smart learners will be able to master the subject matter in a shorter period of time compared to students who are not so smart, which takes longer [12].

The increase in learning outcomes is also calculated by the gain-score. There were 5 students who experienced an increase in the high category because the score-gain was $\geq 0.7$. There are 13 students in the medium category with a score gain between 0.7 and 0.3 while for the low category there are 2 students with scores below 0.3. Although there were 2 students who experienced a low increase but still the posttest scores were completed while there were some students who were not complete but experienced an increase in moderate learning outcomes. The existence of students who are not complete one of them is because based on the observation of the activities of the students at the time of application the game Wind's Maze Chemistry was still at level 1 or only a few people completed the game until the end due to lack of time when the trial was only done for 60 minutes. They keep repeating to read and answer questions due to lack of strategy in avoiding bombs and finding solutions. This shows that there is an effect of Wind's Maze Chemistry as a learning medium for improving student learning outcomes. The game Wind's Maze Chemistry is said to be effective based on the gain score if the results of the increase in learning of students on average reach the criteria of high or medium so that the effectiveness percentage of $90 \%$ is obtained which is in the very effective category.

\section{CONCLUSIONS}

The results of the analysis and discussion show that the game Wind's Maze Chemistry is suitable to be used as a learning medium in the class XI SMA hydrocarbon material. This is based on:

1. Wind's Maze Chemistry game as a learning medium in the developed Hydrocarbon subject matter is declared valid on the game validity requirements by obtaining a very valid category with a percentage of $88.25 \%$ based on the criteria of content validity and construct validity with $90 \%$ and $88 \%$ percentages respectively.

2. Wind's Maze Chemistry as a learning media for Hydrocarbon subject matter that was developed was stated practically on the practicality requirements of the game by obtaining a very practical category with a percentage of $83.75 \%$ based on student questionnaire responses and supported by 94 relevant student activities. $44 \%$ and irrelevant activity of $5.56 \%$.

3. Wind's Maze Chemistry's game as a learning medium on the developed Hydrocarbon subject matter is effective on the game's effectiveness requirements seen from the classical completeness and gain-score with $80 \%$ of each percentage in the effective category and $90 \%$ in the very effective category.

\section{ACKNOWLEDGMENT}

Alhamdulillah, thank you for the presence of Allah SWT who has bestowed His mercy, taufiq and hidayah, so the writer can complete this research. The author also expressed infinite respect and gratitude to Dr. Achmad Lutfi, M. Pd., As a Supervisor who has provided direction, guidance and spent a lot of time to guide the writer in the preparation of this thesis. The family, especially the parents, my father Siswanto and mother Rusmikah and sister Iriene Eka Siswanty who always pray and provide support.

\section{REFERENCES}

[1] Peraturan Menteri Pendidikan dan Kebudayaan Republik Indonesia Nomor 59 Tahun 2014. Tentang Kurikulum 2013 Sekolah Menengah Ats/Madrasah Aliyah. Ditetapkan di Jakarta pada tanggal 2 Juli 2014

[2] Hartina, Aya. T.thn. Model Pembelajaran Kimia Karbon Berbasis Game. e-jurnal (Online: https://www.google.com/url? sa $=\mathrm{t} \& \mathrm{rct}=\mathrm{j} \& \mathrm{q}=\&$ esrc $=\mathrm{s} \&$ source $=$ web \& $\underline{\mathrm{cd}=4 \& \mathrm{cad}=\mathrm{rja} \& u a c t=8 \& v e d=0 \text { ahUKEwj8sN_WmojcAhUSIIgKHV }}$ elAQcQFghMMAM\&url=http $\% 3 \mathrm{~A} \% 2 \mathrm{~F} \% 2$ Fperpustakaan.fmipa.unp ak.ac.id $\% 2$ Ffile $\% 2 \mathrm{Fe}-$ 
jurnal $\% 2520$ Aya $\% 2520 \mathrm{H} \% 2520065112403$.pdf\&usg=AOvVaw2M UG24b2JsSIVt7YjqBTp0 diakses tanggal 7 Juli 2018)

[3] Andiastutik, Etty, Lutfi, Achmad. Pengembangan Permainan Diamond Chemistry Adventure sebagai Media Pembelajaran pada Materi Pokok Hidrokarbon Kelas XI SMA. Journal of Chemical Education, 2017, Vol. 6, No. 2, pp. 212-218.

[4] Prasetyo, Y. D., Ikhsan, J., \& Sari, R. L. The Development of Android-Based Mobile Learning Media As Chemistry Learning for Senior High School on Acid Base, Buffer Solution, and Salt Hydrolysis. Proceeding of International Conference on Research, Implementation and Education of Mathematics and Scuences 2014 Yogyakarta: Yogyakarta State University, 2014.

[5] Hamdani. Strategi Belajar Mengajar. Bandung: Pustaka Setia, 2011.

[6] Zakiyah, Imroatuz dan Poedjiastoeti, Sri. Development of Mobile Gmae Chem Maze As Media In Chemistry learning At Main Topic Periodic System Of Element In Class X. UNESA Journal of Chemical Education, 2015, Vol 4, No 2, pp. 349-356.

[7] Sukmadinata, Nana Syaodih Metode Penelitian Pendidikan. Bandung: PT. Remaja Rosdakarya, 2016.

[8] Smaldino, S. E., D. L. Lowther \& J. D. Russel. Instructional Technology \& Media For Learning: Teknologi Pembelajaran dan Media untuk Belajar. Edisi Kesembilan. Terjemahan Arif Rahman. Jakarta: Kencana, 2011.

[9] Sadiman, Arief S, Rahardjo, \& Haryono, Anung. Media Pendidikan: Pengertian, Pengembangan dan Pemanfaatan. Jakarta: PT. Raja Grafindo Persada, 2014.
[10] Husamah. Pembelajaran Bauran (Blended Learning). Jakarta: Prestasi Pustaka, 2014

[11] Fauzia, Elok, Lutfi, Achmad dan Yonata, Bertha. 2017. The Development Of SABC (Solve Acid Base Case) Game Oriented Android As Instructional Media Acid Base For Eleventh Grade Senior High School. Journal of Chemical Education, 2017, Vol. 6, No. 2, pp. 339-344.

[12] Majid, Abdul. Strategi Pembelajaran. Bandung: PT. Remaja Rosdakarya, 2016.

[13] Slamet, F., \& Hidayah, R. Media Permainan Berbasis Android Catch The Erlenmeyer pada Materi Tatanama Senyawa Kimia untuk Kelas X SMA. Prosiding Seminar Nasional Kimia dan Pembelajarannya (hal. B-135 - B-143). Surabaya: Jurusan Kimia FMIPA Universitas Negeri Surabaya, 2016.

[14] Nur, M. Teori Belajar Kognitif. Surabaya: Unesa Surabaya, 2005.

[15] Prastowo, Andi. Panduan Kreatif Membuat Bahan Ajar Inovatif. Jogjakarta: DIVA Press, 2015.

[16] Riduwan. Skala Pengukuran Variabel-Variabel Penelitian. Bandung: Alfabeta, 2013. 